\title{
'ACTING UPON OUR RELIGION': MUSLIM WOMEN'S MOVEMENTS AND THE REMODELLING OF ISLAMIC PRACTICE IN INDIA
}

\begin{abstract}
$\underline{\text { Abstract }}$
In the last fifteen years, India has witnessed the expression of a variety of new non-conformist religious practices performed by Muslim women. Muslim women's associations have pioneered a range of vibrant campaigns asserting women's claims to hold and lead congregational prayers, enter and manage mosques, visit shrines, officiate Muslim marriages and issue shari 'ah-based legal decisions. This article explores the twin questions of why these experimental re-modellings of women's Islamic observance and leadership have been so pronounced in the Indian context compared with much of the Islamic world, and furthermore, why Muslim women's rights activists have put such confessional matters at the centre of their work. Exploring a series of specific female-led assertions of religious agency centring upon mosques, shari'ah councils and a Sufi shrine, the article argues that India's variant of 'secularism', which has normalised the state's non-intervention in religious institutions and laws, has given women a freedom to embark upon overhauls of Islamic conventions denied to their counterparts elsewhere. Simultaneously, this same framework for handling religious questions has historically given intra-community and clerical voices particular influence in regulating Muslim community affairs and family laws, compelling activists to seek women's empowerment in individual and local community contexts to further their objectives, including through the assertion of experimental forms of religious conduct.
\end{abstract}

\section{Introduction: women's 'religious non-conformism' in India}

“Admion ki bana'i-vi rivaiyat, bana'i-vi prathan ... un sab ko torna, hamen bahut pasand hai." "All the traditions and customs that men have invented... breaking them brings us great pleasure.” (Nishaat Husain, women's rights activist and Islamic ‘qazi', Jaipur). ${ }^{1}$

This article was presented as the Gordon Johnson Annual Director's Seminar at the Centre of South Asian Studies, Cambridge, in 2018, and I am grateful for all the comments provided by the organisers and audience. I am extremely thankful to all the individuals named in the 
In 2003, Asra Nomani, resident of West Virginia and descendant of the Indian Islamic liberal scholar Shibli Nu'mani, wrote a widely reported charter entitled the 'Islamic Bill of Rights for Women in the Mosque.' Written in honour of Hagar, the ancestral Arab matriarch, it argued that mosques should not be reserved for men alone, but that women hold equal claim to worship in mosques and to lead congregational prayers. ${ }^{2}$ Two years later in 2005 , Nomani helped to organise what would become perhaps the defining moment of global exposure for Islamic feminism $^{3}$, when the African American feminist scholar Amina Wadud led the Friday congregational prayers and sermon before a mixed-gender congregation in a mosque in New York. ${ }^{4}$ Less well known is that, following the event, Asra Nomani's journalistic and activist

references for their extraordinary openness and helpfulness in providing me access to their private collections. Additional thanks are due to the Arts and Humanities Research Council for funding the research and to the anonymous reviewers for their helpful suggestions. The opinions expressed in this paper are mine alone.

${ }^{1}$ Interview, Nishaat Husain, 22 August 2017.

${ }^{2}$ Asra Nomani, 'Islamic bill of rights for women in the mosque', http://peprimer.com/islamwomen-rights.html\#SECTION1 [accessed 4 June 2018].

${ }^{3}$ Islamic feminism refers to a global discourse of female equality and justice rooted in a rereading of Islamic scriptures and laws, which emerged in the 1990s-2000s. Pioneered by a number of well-known scholar-practitioners across the Islamic world, it is usually seen to mark a significant shift from the 'secular' rights discourses that previously predominated in women's rights activism in many Muslim-majority nations. For helpful overviews, see Margot Badran Feminism in Islam: secular and religious convergences (Oxford: Oneworld, 2009); Ednan Aslan, Marcia Hermansen and Elif Medeni eds., Muslima theology: the voices of Muslim women theologians (Frankfurt-am-Main: Peter Lang, 2014); Ziba Mir-Hosseini, 'Beyond "Islam" vs "Feminism"”, IDS Bulletin (42, 1, 2011), pp.1-11; Fatima Seedat, 'When Islam and feminism converge', Muslim World (103, 3, 2013), pp. 404-420; Valentine Moghadam, 'Islamic feminism and its discontents: towards a resolution of the debate', Signs 27, 4 (2002), pp. 1135-71.

${ }^{4}$ This landmark event provoked responses of deep commendation and condemnation alike from across the Muslim world. For commentaries, see Juliane Hammer, 'Performing gender justice: the 2005 woman led prayer in New York', Contemporary Islam (4, 2010), pp. 91-116; Meena Sharify-Funk and Munira Kassum, "Where do women "stand” in Islam? Negotiating 
attentions turned to the small town of Pudukkottai in southernmost Tamil Nadu. Here a local women's rights activist, Da'ud Sharifa Khanam, had recently kick-started a campaign to found what she described as the 'world's first women-only mosque'. ${ }^{5}$ While a somewhat hyperbolic claim, her campaign to found a mosque whose prayer-leaders, trustees and guardians would all be female was a statement of radical departure from the norms of South Asian mosque praxis, in which men alone are typically privileged with such roles.

This single women's mosque campaign sat within a wider patchwork of movements emerging across India seeking to question or renovate existing structures of everyday Islamic practice, and to appoint women into positions of religious leadership usually reserved for men. Around the same time, in cities including Mumbai, Lucknow and Jaipur, Muslim women's associations were inaugurating new mosques to allow women's congregational prayer, running women's 'shari 'ah 'adalats' (shari 'ah councils) to offer gender-just advice on Islamic laws, allowing women to officiate at Muslim marriages and setting up Muslim mahila mandals (women's committees) to empower women within family and local environments. In the fifteen years since, a generation of female Muslim activists and leaders of Muslim women's associations have continued to initiate comparable re-modellings of Islamic praxis: a term that I take to refer to the conventions, observances and leadership structures adhered to in normative religious life. ${ }^{6}$ They have promoted a range of women's prayer congregations, devotional acts and

contemporary Muslim prayer leadership in North America', Feminist Review (102, 2012), pp. 41-61; c.f. Amina Wadud, Inside the gender jihad: women's reform in Islam (Oxford: OneWorld, 2006). For Nomani's account of her own similar act in Morgantown, see Asra Nomani, Milestones for a spiritual jihad: towards an Islam of grace (Kalamazoo, MI: Fetzer Institute, 2010).

5 'World's first mosque for women', Hindustan Times (Delhi), 22 October 2007. Nomani took up a fellowship with the South Asian Journalists Association to work on this movement in 2006.

${ }^{6}$ For this definition of religious praxis as the 'expression of religious commitment in practical terms', and for the frequent assumption that Islam places particular emphasis upon rightful conduct as the expression of religious commitment, see Wilfred Cantwell Smith, Islam in modern history (London: Oxford University Press, 1957), p.20; Frederick Denny 'Orthopraxy in Islam and Judaism: convictions and categories', in William M. Brinner and Stephen D. Ricks 
'sisterhoods' (biradarian) of Muslim women, and have organised innovative acts of women's religious observance, leadership and collective assembly.

These activists speak boldly of 'asserting women's existence in the sphere of worship'; they strive to claim (or, as they see it, 'reclaim') women's admission both to Islam's major offices of authority, such as the positions of imam (prayer leader) or qazi (religious judge), and to its religious sites, such as mosques and dargahs (shrines). ${ }^{7}$ They portray themselves as, to quote one activist, 'acting upon our religion (apne din pe 'amal kar-rahe hain)', translating their understanding of Islam into practice with a directness unlike that of previous generations of activists.

Unsurprisingly, these multiple endeavours have divided community opinion. Sympathetic journalists have characterised them as indicative of a wave of women's 'religious nonconformism' that might 'unshackle' women from traditional constraints. ${ }^{8}$ Conversely, these new models of religious action have been much maligned by many among the 'ulama, Islam's amorphous class of clerics, who see them as bid 'ah (innovations) in Islamic norms that could create (fitna) in Muslim society. In 2008, one maulvi memorably dismissed these ruptures of established norms as 'Huma ki ghalatian ka netijah (the result of Eve's mistakes)', , while detractors continue to refer to these religious experiments as 'gimmicks' or 'arranged dramas' that distract from the community's real problems. ${ }^{10}$

eds., Studies in Islamic \& Judaic traditions: papers presented at the Institute for Islamic-Judaic Studies (Atlanta: Scholars Press, 1986-89), vol. 2, pp. 83-95.

${ }^{7}$ Both these religious offices and spaces, they argue, have 'have been for long occupied by patriarchal clergymen,' and are now being 'occupied' by women. Noorjehan Safia Niaz, Women's Shariah Court, Muslim Women's Quest for Justice (Notion Press: Chennai, 2016), pp.i, 45 (this text is a published report on the shari 'ah 'adalat movement authored by the BMMA).

${ }^{8}$ Mohammed Wajihuddin, 'Enter the Islamic feminist', transcript, private collections of Shaista Amber, Lucknow (henceforth: Amber Papers).

${ }^{9}$ As recounted in Shaista Amber, 'Journey of a pedestrian (Peyadah ke safarnamah)', interview transcript (c.2008), Amber Papers.

${ }^{10}$ The Hindu (Chennai), 3 February 2018. 
These overhauls of religious observance seem all the bolder since practices of 'ibadat (Islamic worship) have often been somewhat conservative in South Asia compared to many other Muslim societies. ${ }^{11}$ This may owe to the long-standing influence in the subcontinent of reformist movements such as the Deobandis, Barelwis and Ahl-i-Hadith that emphasise rigid stipulations of religious observance. Alternatively, it may reflect what one activist described as a 'defensive mentality' among Muslims in contemporary India, a reaction to the community's perceived socio-political besiegement that leads community elders and clerics to police religious strictures and demand group subservience, especially by women, to restrictive everyday protocols. ${ }^{12}$ Either way, the women who have advocated these re-modellings of religion have done so in often hostile local environments that are regulated according to maleled religious hierarchies.

Female-led innovations in religious conventions comparable with those in contemporary India have been documented elsewhere in the world. Assumptions of traditionally male Islamic leadership roles and forms of worship by Muslim women have occurred in many regions, especially in the last two decades, with women increasingly visible as prayer-leaders, preachers, religious jurists and judges. ${ }^{13}$ However, the most radical examples have often appeared in a spectrum of Western nations, and a finite number of notably cosmopolitan societies like Malaysia and South Africa. ${ }^{14}$ Studies have therefore often situated these innovations in fluid cultural environments marked by histories of migration, cultural hybridity

${ }^{11}$ The common restrictions upon women's congregational prayer and entry to mosques are examples: see below.

${ }^{12}$ I have heard various variations of this argument from several respondents. For an academic version, see Sameera Khan, 'Negotiating the mohalla: exclusion, identity and Muslim women in Mumbai', Economic and Political Weekly (42, 17, 2007), pp.1527-33.

13 The major summative work on this subject is Masooda Bano and Hilary Kalmbach eds, Women, leadership and mosques: changes in contemporary Islamic authority (Leiden: Brill, 2012).

${ }^{14}$ This observation is made in Masooda Bano and Hilary Kalmbach, 'Islamic authority and the study of female religious leaders' in ibid, pp.23-25. Proving their point, the essays compiled in this volume focus on contemporary assertions of women's leadership chiefly in these same locations, especially Europe. 
and rapid social change. ${ }^{15}$ These studies thus depict environments that feel very different from the conservative everyday Islamic structures at work in much of South Asia, including in the poor urban locales where some of the most audacious examples of women's religious innovation discussed in this paper have taken root.

Moreover, existing scholarship on Muslim women's religious observance in contemporary South Asia has generally traced a rather different trajectory from that documented here. Studies have shown that, especially within the last two decades, the subcontinent has been witness to various tabligh and $d a$ ' $w a$ ' (proselytization) campaigns that are imparting Islamic piety and knowledge to Muslim women. As proven by works on, among others, women's madrasas in north India, the Al-Huda and Jama'at-i-Da'wa' women's groups in Pakistan and women's Qur'anic study circles in Bangladesh and Sri Lanka, Muslim women's piety movements religion have grown in force and number across South Asia. ${ }^{16}$ Yet, most of these studies are

${ }^{15}$ On the particularly Western contexts of new religious practices see many of the essays in Bano and Kalmbach eds., Women, leadership and mosques; Gisella Webb ed., Windows of faith: Muslim women scholar-activists in North America (Syracuse: Syracuse University Press, 2000). One author argues that the diasporic context offers Muslim women an environment to 'reinterpret... the Islamic texts' and 'think... about their religious observances.' Mahmudul Hasan, 'Seeking freedom in the "third space" of diaspora: Muslim women's identity in Aboulela's "Minaret" and Janmohamed's "Love in a headscarf", Journal of Muslim Minority Affairs (35, 1, 2015), pp. 89-90.

${ }^{16}$ E.g. Mareike Winkelmann, From behind the curtain: a study of a girl's madrasa in India (Amsterdam: Amsterdam University Press, 2006); Patricia Jeffery, Roger Jeffery and Craig Jeffrey, 'Leading by example? Women madrasah teachers in rural north India', in Bano and Kalmbach eds., Women, leadership and mosques, pp.195-216; Sadaf Ahmad, Transforming faith: the story of al-Huda and Islamic revivalism (Syracuse: New York University Press, 2009); Humeira Iqtidar, Secularizing Islamists? Jama 'at-e-Islami and Jama'at-ud-Da'wa in urban Pakistan (Chicago: Chicago University Press, 2011), pp.129-55. See also the following articles, all in Modern Asian Studies (42, 2-3, 2008): Farzana Hanifa, 'Piety as politics amongst Muslim women in contemporary Sri Lanka' (pp.347-375); Maimuna Haq, 'Reading the Qur'an in Bangladesh: the politics of 'belief' among Islamist women' (pp.457-488); Elora Shehabuddin, 'Jamaat-i-Islami in Bangladesh: women, democracy and the transformation of Islamist politics' (pp.577-603). 
influenced, directly or indirectly, by the late Saba Mahmood's path-breaking work on women's study circles in the mosques of Cairo, and her framework of women's self-fashioning of their so-called 'pious subjecthood' through the cultivation of personal religious commitment and critical engagement with religion. ${ }^{17}$ These South Asian women, therefore, are deemed to cultivate their own religious autonomy and agency by immersing themselves in religious knowledge and lifestyles; and, like the 'pious subjects' or 'docile agents' of Mahmood's study, they do so in a way that affirms their ultimate conformity with religious teachings and conventions that may, ultimately, be socially conservative and male dominated. ${ }^{18}$ Emphasising women's wilful acceptance of existing Islamic norms, this framework contributes relatively little to understanding the more transgressive re-modellings of religion discussed in this paper which sometimes, as expressed by the activist quoted at the beginning of this paper, take 'pleasure' in deliberately 'breaking' existing patriarchal realities.

This paper seeks to shed light on two interrelated developments in contemporary India: first, the innovative re-modelling of Islamic conventions by Muslim women; and second, the investment of huge energy by a spectrum of female Muslim women's activists and associations in pioneering these revisions. Islamic religious non-conformism and Muslim women's activism, I suggest, have found a strategic alignment in India that is more prominent than for most women's rights movements elsewhere in the Islamic world. I argue that, for a combination of reasons, the distinctive variant of 'secularism' that has taken shape in Indian society and politics has provided a particularly fertile environment for the production of this brand of religious activism. India's 'secular' polity, by setting a context of supposed state nonintervention in religious laws and practices and securing rights to freedom of religion, provides Muslim women with the discursive and operational space to make their own claims to religious authority and action. Simultaneously, I argue, this same polity has persistently framed Muslim

${ }^{17}$ Saba Mahmood, Politics of piety: the Islamic revival and the feminist subject (Princeton: Princeton University Press, 2004). Several of the works cited above explicitly adopt Mahmood's framing concept of pious subjecthood. E.g. Ahmad, Transforming space; Hanifa, 'Piety as politics.'

${ }^{18}$ As Mahmood argued, 'the pious subjects of the mosque movement occupy an uncomfortable place in feminist scholarship, because they pursue practices and ideals embedded within a tradition that has historically accorded women a subordinate status.' Mahmood, Politics of piety, pp.5, 172. 
women as subjects of their religion, bound by community norms as well as state laws; and in doing this, it has compelled activists to defend the equality and rights of women via campaigns of religious, as well as socio-economic, intervention. The manifold Muslim women's associations described in this paper, I show, have all instrumentalised religious practices in different ways, but all of their initiatives are attempts to co-opt the lived, practical realities of religion as means by which they might pursue women's social empowerment.

This paper is an attempt to tell the stories of a spectrum of female Muslim activists from various parts of India including Lucknow, Mumbai, Jaipur and Tamil Nadu, exploring the ways in which they have represented and furthered their attempt to create distinctive female religious spaces and positions of leadership within Islam. The article's next section posits a framework for understanding women's remodelling of religious practice in India, unravelling the interactions between religious non-conformism, women's rights activism and Indian secularism. The subsequent sections focus consecutively upon a series of modern campaigns around India that have sought to open up three distinctively male religious 'spaces' to women: the mosque, the shari 'ah council, and the Sufi shrine.

\section{Muslim women's activism and religious non-conformism in India: explaining}

\section{a convergence}

India has long been host to a range of Muslim women's associations, which together embody a distinctive brand of 'minority feminism'. ${ }^{19}$ Since independence, and especially in more recent decades, a range of separate but loosely interrelated such groups have come into being, among them the Muslim Satyashodhak Samaj (founded in 1970), Awaaz-e-Niswaan (1987), the Women's Research and Action Group (1993) and Muslim Women's Rights Network (1999), both of Mumbai, and the Muslim Women's Forum of Delhi (2000). ${ }^{20}$ Many of these groups

${ }^{19}$ This term is used in e.g. Nida Kirmani, 'Beyond the impasse: 'Muslim feminism(s)' and the Indian Muslim women's movement', Contributions to Indian Sociology (45, 1, 2011), pp.1-26. For general background on Muslim women's movements in India in the postcolonial decades, see Vrinda Narain, Gender and community: Muslim women's rights in India (Toronto: University of Toronto, 2001).

${ }^{20}$ On these and other Indian Muslim women's associations, see the following, and other works by the authors in question: Sylvia Vatuk, 'Islamic feminism in India: Indian Muslim women 
emerged during or after the late-1980s, when the perceived attempts by both the Hindu right and arch-secularists to speak for Muslim women's interests during the Shah Bano affair (19856) compelled some Muslim women to develop community-specific campaigns that were identifiably distinct from mainstream, national women's organisations. ${ }^{21}$

These many Muslim women's associations operate at a mixture of local, state and national levels, and engage in a myriad of activities in pursuance of their aims, ranging from legislative lobbying and public awareness campaigns to litigation and legal aid. They have also sought a careful balance in their relationship with other civil society movements and causes. On the one hand, they adopt a multidimensional approach, aligning themselves accordingly with the wider agendas of national women's associations (e.g. pushing for women's educational and employment rights, and against domestic mistreatment and social discrimination). ${ }^{22}$ Simultaneously, however, these Muslim women's associations have been formed to address difficulties that are specific to the experiences of Muslim women. As is often argued, the particular public and political discourse surrounding Muslim minority rights in India, and the

activists and the reform of Muslim Personal Law', Modern Asian Studies (42, 2/3, 2008), pp.489-518; Mengia Hong Tschalaer, Muslim women's quest for justice: gender, law and activism in India (New York: Cambridge University Press, 2017) and 'Muslim women's rights activists visibility: stretching the gendered boundaries of the public space in the city of Lucknow', South Asia Multidisciplinary Academic Journal (11, 2015), pp.1-19; Nida Kirmani, 'Beyond the impasse' and 'Strategic engagements: analyzing the relationships of Indian and Pakistani women's movements to Islam', Asien (126, Jan 2013), pp.10-25; Rafia Zaman, '(Re)framing the issues: Muslim women's activism in contemporary India', ibid, pp.26-44; Nadja-Christina Schneider, 'Islamic feminism and Muslim women's rights activism in India: from transnational discourse to local movement, or vice-versa?', Journal of International Women's Studies (11, 1, 2009), pp.56-71.

${ }^{21}$ Kirmani, 'Beyond the impasse'; Radha Kumar, The history of doing: an illustrated account of movements for women's rights and feminism in India 1800-1990 (Delhi: Zubaan, 2011), pp.160-9.

${ }^{22}$ On the 'multidimensional' approach of Muslim women's associations and their links with other secular human and women's rights discourses, see respectively Tschalaer, Muslim women's quest; Vrinda Narain, 'Muslim women's equality in India: applying a human rights framework', Human Rights Quarterly (35, 1, 2013), pp.91-115. 
ensuing tendency to frame Muslim women as distinct, even 'unequal' from other female citizens, has meant that the state has often treated Muslim women as a somewhat separate category from other women in social and legal affairs. ${ }^{23}$ In turn, the difficulties faced by Muslim women are often different from those of other female citizens. ${ }^{24}$ The distinctive nature of the Indian Muslim woman's predicament has led Muslim women's associations, while sharing some objectives with cross-confessional women's groups, to work simultaneously within the parameters of religious community. As such, most of these Muslim women's rights groups amalgamate religious and secular reasoning in pursuance of their goals, justifying their campaigns for women's justice and equality via the intersecting principles of the Indian constitution, human rights, and liberal readings of Islamic teachings.

However, despite the heterogeneous character of these many Muslim women's associations, there has been a tangible shift in how some of the most recent among them have instrumentalised matters of religion. The more prominent Muslim women's groups of the 1990s and early-2000s, including those named above, rarely addressed questions of Islamic religious conduct. Instead, they focused (and still do) upon Muslim women's social and legal rights, and did so through a range of initiatives: for instance, by advocating legislative reforms to personal laws, leading public awareness campaigns, facilitating women's access to the judicial system, and offering legal guidance and counselling to women. ${ }^{25}$ These groups were thus generally 'tolerant' rather than 'celebratory' of religion, engaging specifically

${ }^{23}$ E.g. Zoya Hasan and Nivedita Menon, Unequal citizens: a study of Muslim women in India (Delhi: Oxford University Press, 1998); Shahida Lateef, Muslim women in India: political and private realities (New Jersey: Zed Books, 1990).

24 The Muslim personal law system, which adjudicates Muslims' marital and family lives according to a separate body of Islamic family laws, is a key example of how the state has normalised a very different socio-legal predicament for Muslim women.

${ }^{25}$ This holds true for movements named above including Awaaz-e-Niswaan, the Women's Research and Action Group, the Muslim Women's Forum; as well as other women's associations that work extensively but not exclusively with Muslim women, such as Majlis of Mumbai (founded 1991) and the Association for Advocacy and Legal Initiatives of Lucknow (founded 1998). 
confessional matters such as the reformulation of religious authority or practices of worship only rarely. ${ }^{26}$

Subsequently, in the last fifteen years, a clear second generation of Muslim women's organisations have emerged that combine campaigns for women's socio-economic and legal rights with simultaneous demands for their rights within specifically religious praxis. Organisations such as the Muslim Women's Jama'at of Tamil Nadu (founded in 2004), the All India Women's Personal Law Board of Lucknow (2005), and the Bharatiya Muslim Mahila Andolan (Muslim Women's Movement of India, 2008) mark a tangible shift in agenda and strategy by Muslim women's activists. ${ }^{27}$ Compared to their antecedents, these organisations have engaged in a more direct challenge to the regulations of everyday religious life.

Significantly, this particular convergence of Muslim women's activism and religious nonconformism differs not just from its antecedents in India, but from women's rights movements and organisations in many other parts of the Muslim world. Women's associations in Muslim majority states have generally focused upon a range of social, economic and legal causes analogous to those being pursued Muslim women's associations in India: the details vary by country, but generally include campaigns to influence reform family laws (for instance, laws on polygamy, divorce or inheritance rights), protect women from social abuses (e.g. forced marriage, marital mistreatment or domestic violence), or advance women's access to education and employment. ${ }^{28}$ In light of their core focus upon women's socio-economic, legal and

${ }^{26}$ Kirmani, 'Beyond the impasse', p.16, c.f.11-12.

27 For these organisations, see the works cited above, fn.20, especially those works by Tschalaer, Vatuk and Kirmani. Despite some synergies between their activities, these organisations are not formally linked to each other, and have their own particular perspectives and agendas.

${ }^{28}$ This chiefly socio-political agenda is common to all of the most studied women's movements in Muslim-majority societies, such as those in Turkey, Egypt, Morocco, Tunisia and elsewhere. Valentine Moghadam, Modernising women: gender and social change in the Middle East (Boulder: Lynne Reinner Publishers, 2003); Nadje al-Ali, Secularism, gender and the Middle East: the Egyptian women's movement (Cambridge: Cambridge University Press, 2000); Amy Evrard, The Moroccan women's rights movement (Syracuse: Syracuse University Press, 2014); Omar Caha, Women and civil society in Turkey: women's movements in a Muslim society (New 
political rights, these associations have engaged points of religious praxis only marginally. They have generally paid scant attention to issues such as women's mosque entry or prayerleadership, which might seem like peripheral, unnecessarily divisive and strategically unwise diversions from their broader objectives. ${ }^{29}$

That Muslim women's activists in India have engaged so directly with attempts to amend religious norms and behaviours thus warrants investigation on its own terms. These activists themselves sometimes justify their focus on such matters on the basis that Muslim women face multiple challenges, and thus those seeking to promote their rights need to adopt a multipolar approach. As one leading activist argues, Muslim women in India are 'triply disadvantaged': by their gender; by patriarchal understandings of religion; and by their status within an often marginalised and stigmatised minority community. ${ }^{30}$ Their problems derive from religious and cultural as well as socio-economic and legal roots, meaning that activists have been compelled to address all of these many sources of women's disempowerment alongside each other.

Yet, I suggest in this article that the reasons why female activists in contemporary India have taken up matters of religious praxis with such determination rest within India's particular legalconstitutional framework for handling religious questions: namely, its own version of 'secularism'. As many analysts have argued, India has developed a 'distinctively Indian', 'context specific' and perpetually negotiable variant of secularism by which the state, somewhat contradictorily, pledges to refrain from interfering in the laws and practices of religious communities, while simultaneously giving citizens constitutional protection from

York: Routledge, 2013). Pakistan's women's movement is another case in point: it was consolidated in the 1980s chiefly to oppose the penal Hudood Ordinances and other judicial injustices faced by women, and tended to frame itself in the principles of universal human rights. See Ayesha Khan, The women's movement in Pakistan: activism, Islam and democracy (London: I.B. Tauris, 2018).

${ }^{29}$ Ziba Mir-Hosseini claims that Muslim women's movements have tended to give 'moral support' rather than substantive assistance to overhauls of confessional praxis (oral communication, 21 April 2018). Indeed, none of the studies of women's movements in Muslim-majority societies cited in ibid suggest that these movements have ever given more than fleeting attention to questions of religious conduct, if any at all.

${ }^{30}$ Interview, Zakia Soman, 25 May 2018. 
forms of inequality and discrimination that arise from religious customs. ${ }^{31}$ India's variant of secularism, for several reasons, has provided a supportive milieu for the rise of this brand of confessionally-engaged women's activism.

One factor that shapes Muslim women's activism in India - contestable but often alluded to by activists - is that the state's pledged non-intervention in religious beliefs and practices permits more scope and space for women's groups to engage autonomously with questions of religion than has been available to them in many Middle Eastern or Asian states. In many Muslim majority nations, religious institutions are subjected to state supervision or regulation of various kinds. Some regimes, for instance, regulate institutions such as mosques, madrasas (religious schools) or waqfs (Muslim endowments), or insist upon the licencing of imams or religious teachers. ${ }^{32}$ Most Muslim nations have also legislated upon or even fully codified Islamic family laws. ${ }^{33}$ In these contexts in which the state has taken on a proactive role in the management of

${ }^{31}$ E.g. Rajeev Bhargava, 'The distinctiveness of Indian secularism', in T.N. Srinivasan ed., The future of secularism (Delhi: Oxford University Press, 2007), pp. 20-1; 36-40. A number of other analysts too diverse to discuss here have considered India's unique style of secularism as an ideology or strategy for the contextual handling of questions of cultural and religious autonomy. For representative examples, see T.N. Madan, Modern myths, locked minds: secularism and fundamentalism in India (Delhi: Oxford University Press, 2010); Gary Jacobsohn, The wheel of law: India's secularism in comparative constitutional context (Princeton: Princeton University Press, 2005); Anuradha Dingwaney Needham and Rajeswari Sunder Rajan eds., The crisis of secularism in India (Durham: Duke University Press, 2010); and others cited below.

${ }^{32}$ For just a few examples of state 'management of religion' in the Islamic world, see Jakob Skovgaard-Petersen, Defining Islam for the Egyptian state: muftis and fatwas of the Dar alIfta (Leiden: Brill, 1997); Jamal Malik, Colonialization of Islam: dissolution of traditional institutions in Pakistan (Delhi: Manohar, 1996); Thomas Pierret, 'State management of religion in Syria: the end of “indirect rule"?' in Steven Heydemann and Reinoud Leenders, Middle Eastern authoritarianisms: governance, contestation and regime resilience in Syria and Iran (Stanford: Stanford University Press, 2013). See also the works cited below in fn. 47.

${ }^{33}$ For overviews of the juridification of Islamic family law by postcolonial Muslim majority nations, see e.g. Wael Hallaq, Shari'ah: theory, practice, transformations (New York: 
religion, the abilities of activists to challenge existing religious norms has been somewhat restricted; their challenges to religious structures are at risk of being interpreted as acts of societal or political subversion. ${ }^{34}$ By contrast, the assumption of what Rajeev Bhargava refers to as the state's 'principled distance' from religion that is embedded in India's variant of secularism has left minority religious institutions comparatively free from official involvement. ${ }^{35}$ India has no formally recognised Islamic clerical body or council equivalent to those in many Muslim societies, while Islamic religious schools and the community bodies governing mosques, shrines and other institutions operate largely unfettered by state regulations. This unregulated religious framework, within which there is no 'official' Islamic voice or hierarchy to represent the community, permits more scope for activists and other practitioners to tinker with conventional Islamic conduct according to their own inclinations.

However, while India's unique variant of secularism can thereby empower women's groups to speak on matters of religion, it can simultaneously facilitate women's disempowerment at the hands of structures of religious community. India's secular framework, affirming that religious minority communities should be permitted to live according to their own laws and values, has meant that Muslim community structures have remained largely free from state involvement. In turn, this has given community leaderships and institutions considerable sway over the everyday regulation of Muslim community affairs. ${ }^{36}$ India's Muslim personal law system, by

Cambridge University Press, 2009) pp.443-499; Jan Michel Otto ed., Sharia incorporated: $a$ comparative overview of the legal systems of Muslim countries (Leiden: Leiden University Press, 2011).

${ }^{34}$ The works cited in above in fn. 28 often hint at the frequent suspicion with which these states have viewed women's rights movements within their borders.

${ }^{35}$ This phrase is taken from Bhargava, 'The distinctiveness of Indian secularism', pp.39-41.

${ }^{36}$ Partha Chatterjee especially has elaborated upon the 'paradox' that Indian secularism, which simultaneously incurs state involvement and non-interference in religion and has had different implications for the Hindu majority and religious minorities. He argues that the religious laws and institutions of the latter have been subject to fewer state interventions; and that in the case of Indian Muslims, secularism has empowered an ill-defined, non-state Muslim 'leadership' to regulate community institutions. Partha Chatterjee, 'Secularism and toleration', Economic and Political Weekly (29, 28, 1994), pp.1768-1777 and The politics of the governed: reflections on popular politics in most of the world (Delhi: Permanent Black, 2004), pp.115-128. 
which Muslims are subject to a separate and distinct body of religious family laws, is perhaps the key example. By comparison with most Muslim-majority nations, Muslim family laws in India have been very little codified, and are adjudicated in practice by a range of both stateand non-state legal forums, including both the civil and family courts and a range of informal, largely autonomous religious and community bodies such as mosque jama'ats (committees), panchayats (local community councils) and dar-al-qazas (non-judicial Islamic 'courts'). ${ }^{37}$ This complex, pluralised legal framework gives religious leaders and community bodies a level of social and legal command that has major implications for women. As one activist puts it, the Muslim personal law system creates local realities in which women are subjected to the whims of male maulvis and so-called 'fatwa-happy institutions', living under perpetual threat of marital abuses like immediate unilateral divorce (talaq-i-bid'ah), the withholding of spousal maintenance or involuntary subjection to polygamous marriage. ${ }^{38}$

India's legal-constitutional framework for handling the laws and institutions of the Muslim minority is thus very different from the approach of most Muslim-majority states, where such religious questions have been subject to various kinds of regulation by official or semi-official bodies. In turn, these different frameworks have determined the strategies followed by women's activists in these different centres. In most Muslim majority-states, where the state has had a greater hand in regulating religious laws and institutions, women's rights movements have often attempted to incur state involvement to achieve their objectives, by lobbying parliamentarians, promoting women's access to legal services, or creating political will through public awareness campaigns. ${ }^{39}$ In India, however, the strategy followed by Muslim women's activists is somewhat different. While they too actively lobby politicians and engage the courts

\footnotetext{
${ }^{37}$ On the significant role of non-state community bodies in adjudicating Muslim personal laws, see e.g. Gopika Solanki, Adjudication in religious family laws: cultural accommodation, legal pluralism and gender equality in India (New York: Cambridge University Press, 2011), pp.267-332; Sylvia Vatuk, Marriage and its discontents: women, Islam and the law in India (Delhi: Kali for Women, 2017); Katherine Lemons, Divorcing traditions: Islamic law and the making of secularism (Ithaca and London: Cornell University Press, 2019); Flavia Agnes and Shoba Venkatesh Ghosh eds., Negotiating spaces: legal domains, gender concerns and community constructs (Delhi: Oxford University Press, 2012). See also below, fn. 69.

${ }^{38}$ Sharat Pradhan, 'Sisters in arms', manuscript, Amber Collection.

${ }^{39}$ This is the case for all the movements cited in fn. 28 .
} 
to work towards their goals, they are also working in a situation in which the state's mandate is limited. India's activists thus 'cannot work through the legislature' alone to obtain changes to family laws or other woman-friendly reforms, as perhaps they could within more centrally regulated legal-political frameworks. ${ }^{40}$ Instead, they can only effect meaningful transformations if they combine official approaches with counterpart initiatives that concentrate on establishing changes in what respondents called 'mindsets' or 'mentalities' at community level. ${ }^{41}$ This has laid the basis for a less state-oriented, more ground-level and informal strategy for India's Muslim women's activists, that seeks to establish a consciousness of women's equality not simply in written law or official arenas, but within community structures. $^{42}$

This helps to explain why Muslim women's activists in India have engaged so directly with religious practices. Conscious of the limits of official and state-centred mechanisms to further Muslim women's needs, a new generation of activists have increasingly pursued a non-state strategy to effect grassroots change. ${ }^{43}$ They have aspired to renovate informal and community realities in order to emancipate individual women - socially, emotionally or mentally - within their everyday lives; and they have instrumentalised religious piety (diyanat) to do so. As expressed by Nishaat Husain, the activist (and 'qazi') quoted at the beginning of this paper, women need to recover religion as the source of their own personal 'power' and agency (shakti, quwwat), rather than accepting it as a source of their oppression. ${ }^{44}$

\footnotetext{
${ }^{40}$ Judith Tucker, Women, family and gender in Islamic law (Cambridge: Cambridge University Press, 2008), p.127.

${ }^{41}$ Respectively Amber, 'Journey of a pedestrian'; interview, Zakia Soman.

${ }^{42}$ C.f. Tschalaer, Muslim women's quest.

${ }^{43}$ I suspect that the beginnings of these religious experimentations, around 2004-5, owe in part to an increasingly acute sense that the state had proven powerless in its efforts to improve the normative conditions of the Muslim community, and of Muslim women in particular. This was evidenced both by the increase in anti-Muslim violence (2002); the findings of the Sachar Committee Report (2006); and the ongoing reluctance of the legislature to engage in codification or overhaul of personal laws.

${ }^{44}$ Interview, Nishaat Husain.
} 
Nevertheless, there are distinctions in how the activists discussed in this paper have instrumentalised religious praxis to deliver this 'power' to Muslim women. Sometimes, women's activists assign a chiefly inspirational role to religion, claiming that the recovery of women's ability to worship or to express Islamic opinions can provide individual women with the courage to subsequently assert their social and legal rights in all areas of life. In other cases, these activists have conceived their renovations of Islamic practices as themselves transformative, since these ruptures directly undermine the norms that underpin social patriarchy. Thus, while the several campaigns described below differ among themselves in their manners of remodelling religion and their attitudes towards existing conventions, all share a comparable emphasis upon the remodelling of Islamic conduct as the basis for a recovery of women's spiritual and social empowerment.

\section{Women claiming the mosque}

In the last fifteen years, journalists have sometimes referred to a 'women's mosque movement' ('auraton ki masaajid ki tehrik) in India. ${ }^{45}$ While in reality there has not been such a singular movement as this, there have been several individual campaigns to open up the religious life of the mosque to greater female participation. These have included campaigns by women to found mosques; and for the foundation of mosques whose main congregational spaces are accessible to women; or which are reserved for female worshippers; or which are staffed by female imams. Recently, there have also been major attempts to push the boundaries of women's prayer practices.

Notwithstanding certain strictures within the classical Islamic law schools on women's access to mosque worship, there are long-term historical precedents in Islamic thought for women attending mosques and acting as congregational prayer-leaders. ${ }^{46}$ Likewise, in much of the contemporary Islamic world the prayer spaces of mosques are accessible to female

\footnotetext{
${ }^{45}$ E.g. 'World's first mosque for women', Hindustan Times, 22 October 2007.

${ }^{46}$ Marion Katz, Women in the mosque: a history of legal thought and social practice (New York: Colombia University Press, 2014). Another useful summary of hermeneutic arguments legitimising female-led prayer and mosque worship is available in Ahmed Elewa and Laury Silvers, "I am one of the people": a survey and analysis of legal arguments on woman-led prayer in Islam', Journal of Law and Religion (26, 1, 2010), pp.141-171.
} 
worshippers. Female prayer-leaders (imamahs) have been trained and appointed to mosques in many Muslim societies, both through official government support or grassroots demand ${ }^{47}$, while there are even women-only mosques in some countries. ${ }^{48}$ However, for the reasons previously discussed, women's access to the life of the mosque in South Asia remains generally restrictive in comparison. Many mosques in South Asia remain male-only spaces, or in other cases, only admit female worshippers to peripheral sections such as side-rooms, cellars or balconies. ${ }^{49}$ Female-led public or mosque-based congregational prayers, while not unknown, remain somewhat exceptional in India. ${ }^{50}$ South Asian fatwas on prayer frequently emphasise that men should pray in congregation while women may simply pray at home, and some prominent fatwas forbid women from leading prayers in any context. ${ }^{51}$

47 For government-led appointments of female imams as a form of state-led Islamic modernisation, see e.g. Margarent Rausch, 'Women mosque preachers and spiritual guides: publicizing and negotiationg women's religious authority in Morocco' in Bano and Kalmbach eds., Women, leadership and mosques, pp.59-84; and Mona Hassan, 'Reshaping religious authority in contemporary Turkey: state-sponsored religious preachers', in ibid, pp.85-104. For grassroots movements for the appointment of female imams, see other essays in ibid, and works cited above, fn. 4 .

${ }^{48}$ China is the key example, e.g. Maria Jaschok and Jingjun Shui, The history of women's mosques in Chinese Islam: a mosque of their own (Richmond: Curzon, 2000). There have also been various efforts to set up women 's mosques in a range of Western societies in the last few years, including in the USA, Germany, Denmark, Spain and the UK.

${ }^{49}$ As one maulvi from Tamil Nadu rather self-defeatingly put it: 'women should have the right to offer prayers in mosques: in at least five percent of our state's mosques, there are separate enclosures for women.' Anand, 'A masjid for Sajida'.

50 There are isolated instances of the holding of women's public prayer meetings: for instance, a Muslim women's organisation of Lucknow, the Bazm-i-Khawateen, has been holding salat$i$-tasbeeh women's prayer assemblies to break the 'Eid fast in a public park in the city for some 75 years. Tschalaer, 'Muslim women's rights activists' visibility', pp.6-7.

${ }^{51}$ Recent Deobandi fatwas suggesting that women should conduct salah and taraweeh prayers at home rather than in the mosque include nos. $1520 / 1521 / \mathrm{M}=1430$ (2009); 1808/D=283/K=1430 (2009) 208/208/M=1433 (2012); 1449/1102/B=11/1434 (2013); 1049/1049/M=11/1436 (2015), all of which are available via the website of the dar-al-ifta at 
Recent years, however, have seen several prominent efforts at transforming these regulatory norms of mosque-based worship. A striking, early effort to allow women access to the life of the mosque was led by Shaista Amber, the energetic founder of the All India Muslim Women's Personal Law Board (AIMWPLB), an organisation that advocates reforms to Muslim personal laws and other community causes. ${ }^{52}$ Renowned as a committed Marxist before becoming a Muslim women's rights activist, and currently known as 'Godmother' by some admirers, Amber has built a career in which she combines interventions in national media and legislative debates on women's rights, especially on Muslim personal law reform, with ground-level social work among women in her neighbourhood of southern Lucknow. Yet, her formation of the AIMWPLB in 2005 was in fact foreshadowed by an earlier, more locally focused effort to establish a mosque. In a trope common to India's feminist activists, Amber links the mosque campaign to her own life-story. ${ }^{53}$ She recalls not being able to accompany her young son to her neighbourhood mosque, and how this ignited her desire to build a mosque herself; she further recalls that, living near a major hospital, she often met women who desperately wanted to pray for ill relatives but had nowhere to go. ${ }^{54}$ Initially she proposed a women-only mosque, though this later developed into proposals for a mixed-congregation mosque with allotted spaces for women. She invested her personal wealth (and sold jewellery) to secure the plot of land; and equally crucial to her was moral support from the scholar she refers to as 'my marja' my shaikh', the renowned principle of the Nadva't ul-'Ulama seminary Abul Hasan 'Ali Nadvi, who offered support to her campaign and laid the foundation stone in $1999 .{ }^{55}$

Deoband: http://www.darulifta-deoband.com/home [accessed 15 May 2019]. For comparable historical decisions, see Rashid Ahmad Gangohi, Fatawa-i-Rashidiyya (Delhi: Da'irat-iMa'arifat, 2008), pp.38-40; Ahmad Raza Khan Barelwi, Fatawa-i-Rizviyya (Karachi: Da'wa't al-Islami, 2005), Vol III, pp.102-144.

${ }^{52}$ For background on the AIMWPLB, see the works cited above in fn. 20, especially the second chapter of Tschalaer, Muslim women's quest.

53 Amber offers an autobiographical account of her campaign in Amber, 'Journey of a pedestrian.'

54, Shaista Amber, oral communication, 22 March 2014.

55 Shaista Amber, 'Mufakkir-i-Islam', 'Aalami Sahara (Lucknow), 30 April 2007, Amber Collection. 
Ultimately, the 'Anbar Masjid (perhaps deliberately often misnamed the 'Amber Masjid' by her detractors to imply her alleged self-importance, although the actual name refers to the mosque's pearl-grey tint) opened to worshippers around 2004. Mixed-gender congregational prayers are led in the mosque by a male imam, but while women conduct prayers behind the male congregation, they do so in the same congregational space. Moreover, an additional, upstairs area in the mosque is reserved for women alone, and Amber and other women sometimes lead female-only salat prayers in the mosque. And Amber claims that the number of women travelling to the mosque to join in prayers is increasing year by year.

To legitimise shared spaces of worship, Amber looks to women of Islamic history. She invokes Hazrat Bibi Hafsa, one of the Prophet's wives, who acted as imam and led prayers for female congregations. Historically, she notes, women in India have founded mosques: for instance, Malika Jahan Begum, wife of Awadh's former king Muhammad 'Ali Shah, completed the jama' masjid in Amber's hometown of Lucknow following his death. ${ }^{56}$ Amber also argues that she is recovering the Prophet's original ethos of the mosque, when it was not as now a place for reinforcing male custody of worship, but an open institution of social provision serving the whole community. Reclaiming this broad vision of the mosque as a place of community service, she notes that the 'Anbar Masjid provides many women who only rarely leave their homes with a 'place to go', a space to 'gather, discuss, share their problems. ${ }^{57}$ Recovering the mosque's original status as an institution of social compassion, her mosque contains a counselling centre (or shari'ah 'adalat - see below) for women, and a shelter and refuge to provide for the poor of any community. Moreover, the mosque maintains permanent aspirations to be at the vanguard of innovation: recently, it has become India's first mosque to run entirely on solar power.

An equally path-breaking campaign has been a long-term movement for a women-only mosque in south India, serviced by an entirely female staff as imam, mu'ezzin and trustees. This campaign has been championed by Da'ud Sharifa Khanam, an activist who leads a 3000-strong NGO named the Muslim Women's Jama'at (also known as Steps) that provides counselling and other aid to marginalised women in the southern districts of Tamil Nadu. Like Amber, Sharifa carries a well-rehearsed autobiography which she links to her mosque movement. As

\footnotetext{
56 'Separate mosques for women demanded', Amber Collection.

${ }^{57}$ Shaista Amber, oral communication.
} 
she tells it, she remains unmarried: the youngest of ten children, her parents had been unable to afford the customary dowry. ${ }^{58}$ Sharifa tells how she was able to obtain local support in the district of Pudukkottai to begin a fundraising campaign to establish a women-only mosque. The mosque has a plot of land allotted to it by a generous local benefactor but, predictably, the construction of the mosque remains as yet unfulfilled. It has come up against numerous challenges, including local bureaucracy, and opposition from the Muslim Munnetra Kazhagam, the Tamil Islamist organisation connected with many of the province's mosques. Nevertheless, the campaign continues. As Sharifa has put it, 'all I want is my mosque to become the nerve centre of a vibrant, Islamic, feminist and democratic culture. ${ }^{59}$

Da'ud Sharifa's mosque movement is a clear attempt to challenge the internal structures of hierarchy within Muslim communities. Every mosque in Tamil Nadu, she explains, is run by a jama 'at: a council of community elders, almost always exclusively male, that is locally authoritative and issues directives on all kinds of intra-community affairs including marriage, divorce, dowry, custody and domestic abuse. The 'mosque-jama 'at axis', Sharifa argues, represents a 'power centre,' an undeclared 'kangaroo court' that makes decisions dictating women's lives in male-only spaces, and without soliciting any participation from the women affected. ${ }^{60}$ This power held by male jama 'ats, Sharifa explains, compelled her to begin setting up an all-female equivalent. In 2004, she established the Tamil Nadu Muslim Women's Jama'at, a community body that she proudly calls the world's first women's jama 'at, and a conscious counterweight to the power of the mainstream mosque bodies. The organisation, which is now said to have branches in almost half of Tamil Nadu's districts, invites any woman who has not been given justice by her local mosque committee to submit an account of her

\footnotetext{
${ }^{58}$ Anand, 'A masjid for Sajida'; Shafee Ahmed, 'The lady of 'Women's Jamaat', 6 September 2009, http://twocircles.net/2009sep05/lady_women_s_jamaat.html [accessed 26 January 2018].
}

59 Lakshmi Subramanian, 'A feminist force', India Today, 26 June 2008, https://www.indiatoday.in/magazine/cover-story/story/20080707-feminist-force-736705-

2008-06-26 [accessed 5 March 2018].

${ }^{60}$ Some activists speak of Tamil Nadu's mosque jama 'ats as 'structures of patriarchy' that prevent women from receiving local justice, noting that even the police will often send vulnerable women to their jama'at to handle their problems. Interview, Jaib-un-Nisha, 15 August 2017; Anand, 'A masjid for Sajida'. 
grievances, upon which the Jama'at approaches the mosque in question to demand redress. ${ }^{61}$ But, she argues, for the Women's Jama'at to have the same authority as a male equivalent, it needs a comparable appearance; and 'since a jama' at is attached to a mosque, we have to build our own mosque. ${ }^{62}$

There are of course slightly different accents to the arguments used by Amber and Sharifa. Amber is clear that she herself was only empowered to found the AIMWPLB and begin her quest for legal reforms after establishing her mosque: 'it is that mosque where Allah granted me the opportunity to take the most important decision of my life, to set up the All India Women's Personal Law Board. ${ }^{93}$ She thus reasons that access to a mosque may give women confidence and self-worth that can inspire them in other facets of their lives, as it did for her. For Sharifa, there is a greater emphasis upon the desired mosque as a direct overhaul of the everyday hierarchies of religion and a structural challenge to male jama 'ats. Nevertheless, there is an intuitive connection between these two campaigns in their desire to approach sociallegal questions through community-level religious observance. Both movements' leaders identify the local mosque, rather than the court or bureaucracy, as the most effective point of approach for empowering women; and both believe that creating a new mosque may ultimately exercise real change in India's community structures. Both, in other words, are calculating that questions relating to women's social and religious rights are in various ways interconnected, and must be addressed together.

These two examples have paved the way for some even more audacious moves by female activists to assert women's agency to worship in mosques or lead prayers in recent years. An especially striking recent intervention came in the otherwise anonymous village of Cherukode in Kerala's Mallapuram district in January 2018. Here, K. Jameetha 'Teacher', an administrator within a local religious organisation known as the Khuran Sunnath Society, 'followed the footsteps of Amina Wadud and Asra Nomani' and purportedly became India's first woman to lead the juma ' $h$ prayer and sermon before a mixed-gender congregation of approximately 80

\footnotetext{
${ }^{61}$ Subramanian, 'A feminist force'.

${ }^{62}$ Ahmed, 'The lady of 'Women's Jamaat'.

${ }^{63}$ Shaista Amber, oral communication; Amber, 'Journey of a pedestrian'.
} 
worshippers. ${ }^{64}$ While the venue for the event was an office rather than a mosque, the notion of a woman leading even men in prayer made this perhaps the most controversial of the acts described here, and it led to scorn and threats of vigilante-ism from conservative opponents. ${ }^{65}$

Like the earlier mosque movements discussed above, Jameetha's remodelling of confessional practice can be interpreted as a step towards a broader programme of structural religious reform. The organisation at the heart of the event, the Khuran Sunnath Society, had been founded to disseminate the teachings and work of the Islamic scholar Chekanoor Maulavi, a known 'Qur'anist' ${ }^{66}$ Like the 'Qur'anist' and anti-hadith reformist movements that have had had long influence in countries like Malaysia, Pakistan and the USA (but rather less in India where conservative Hanafi interpretations remain dominant), the Khuran Sunnath has advocated a return to the Qur'an alone as the sole basis for developing ethically conscious norms of social conduct. ${ }^{67}$ The organisation has also encouraged the rejection of the hadith, and later tradition of fiqh (jurisprudence), as a means of unlocking Islam's progressive instincts. Like Islamic feminists more widely, the Khuran Sunnath has considered a return to the Qur'an as a means of enhancing women's rights both in religious practices such as prayer leadership and mosque attendance, but also in matters of Islamic family laws. ${ }^{68}$ To put this another way, Jameetha's visible renovation of prayer conventions carried the subtext of rejecting existing

${ }^{64}$ Arshad Alam, 'Women leading mix gender prayers: smashing patriarchal certainties', New Age Islam, 29 January 2018, https://sabrangindia.in/article/women-leading-mix-genderprayers-smashing-patriarchal-certainties [accessed 22 February 2018].

${ }^{65}$ E.g. Deccan Chronicle (Hyderabad), 28 January 2018; Times of India (Mumbai), 29 January 2018 .

${ }^{66}$ Chekanoor Muhammad Abul Hasan Maulavi was a controversial Keralan Islamic orator and writer who died in mysterious circumstances, presumed assassinated, in 1993.

${ }^{67}$ For background on the 'Qur'anist' tendency, see Aisha Musa, 'The Qur'anists', Religion Compass (4, 1, 2010), pp.14-21. For its early roots in South Asia, see Ali Usman Qasmi, Questioning the Authority of the Past: the Ahl al-Quran Movements in the Punjab (New York: Oxford University Press, 2011).

${ }^{68}$ For instance, in 2015 the Khuran Sunnath filed a case in the Kerala High Court demanding equal rights of inheritance for Muslim women, in defiance of existing Muslim personal laws. https://indiankanoon.org/doc/198258172/ [accessed 24 July 2019]. 
conventions of figh, and thereby initiating greater equality and justice for women in all areas of Muslim social relations.

\section{Women claiming the court}

If the mosque represents one normatively 'male' religious space that reinforces patriarchal authority, then the shari 'ah court (shari 'ah 'adalat, dar-al-qaza) represents another. India's variegated institutional structure for the handling of personal laws ensures that such Islamic religious courts, which offer shari 'ah-based decisions on personal and family affairs such as marriages and divorces, exist in numbers in India. ${ }^{69}$ While holding no official legal jurisdiction, they are highly influential at a non-state level, especially as a result of the increasing sway held by so-called 'alternative dispute resolution' (ADR) mechanisms since the $1990 \mathrm{~s} .{ }^{70}$ By the usual understandings perpetuated by the qazis (Islamic judges) who preside in these courts, most of whom follow largely conservative Hanafi teachings, a qazi has to be male. This is despite the fact that it is women who are often compelled to approach these shari 'ah courts. The disparities in the matrimonial rights granted to Muslim men and women in India under Islamic family law (for instance, wives unlike husbands need to secure the intervention of a male qazi in order to initiate a marital separation, while a husband can do so unilaterally), together with a frequent lack of kinship or community support for women in fractious family situations, mean that most of those who seek out a qazi for advice, representation or arbitration tend to be women. ${ }^{71}$

It is therefore perhaps unsurprising that, when Muslim women's activists have addressed the everyday workings of religion, they have sometimes prioritised reconsidering and

${ }^{69}$ On these shari 'ah dispute resolution bodies in India, see Katherine Lemons, 'Sharia courts and Muslim personal law in India: intersecting legal regimes', Law and Society Review (52, 3, 2018), pp.603-629; Jeffrey Redding, 'The case of Ayesha, Muslim 'courts' and the rule of law: some ethnographic lessons for legal theory', Modern Asian Studies (48, 4, 2014), pp.940-85; Sabiha Husain, 'Shariat courts and question of women's rights in India', Pakistan Journal of Women's Studies (14, 2 2007), pp.73-102.

${ }^{70}$ See above, fn. 37; also Srimati Basu, The trouble with marriage: feminists confront law and violence in India (Delhi: Orient Blackswan, 2015), pp.94-96.

${ }^{71}$ For the attendance of women in shari 'ah councils, see Husain, 'Shariat courts'; Redding, 'The case of Ayesha'; Vatuk, Marriage and its discontents, especially pp.118-34. 
appropriating the office of the Islamic qazi (religious judge). From around 2004-5, several Muslim women's organisations, including the All India Muslim Women's Personal Law Board and the Muslim Women's Jama'at as discussed above, were running their own shari'ah 'adalats, chiefly as counterweights to Lucknow's madrasa-based shari 'ah courts and Tamil Nadu's mosque brotherhoods respectively. These forums were non-official counselling, legal aid and arbitration organisations, though ones that often justified their advice on 'Islamic' grounds of reasoning.

The same years also saw, amidst much publicity, women taking up another central function of the qazi: that of marriage registrar. In Lucknow in 2008, Syeda Hameed, a planning commissioner who worked for the Uttar Pradesh state government, accepted an invitation to act as qazi to officiate the marriage of a local women's rights activist, Na'ish Hasan. Additionally, Hasan's nikah was, contrary to tradition, witnessed by four women (some of whom comprised the circle who were currently establishing the BMMA). Hameed herself worked explicitly to defend a woman's ability to assume such a customarily male position. 'During the days of pristine Islam,' she argues, 'there must have been women qazis, but there is no historical record [either] to prove or disprove their existence.' Their presence, however, can be inferred from the 'inexorable fact' that the arrival of Islam brought 'women's empowerment in... marriage, property, business and matters of religion. ${ }^{72}$ Hasan, along with the marriage's various officiates and much of the press, were unanimous in declaring the event to be one with 'no precedent... in recent Muslim history', one that 'smashed a glass ceiling' in affirming women's rights to take charge of their own marital choices, contracts and ceremonies. $^{73}$

Perhaps taking a lead from this first adoption of the status of qazi, the BMMA ultimately initiated the creation of a more systematic, self-proclaimed all-India 'movement' to establish

\footnotetext{
72 Syeda Hameed, 'When a woman conducts the nikah', http://www.indiatogether.org/nikahwomen [accessed 11 January 2019].

73 Na'ish Hasan, oral communication, 24 March 2014; Tschalaer, 'Muslim women's rights activists' visibility', pp.9-11; The Telegraph (Delhi), 12 August 2008; The Hindu, 13 August 2008.
} 
women's shari 'ah 'adalats across India. ${ }^{74}$ In 2013, it set up its first four 'women's courts': in Mumbai, Pune, Ahmedabad, and Dindigul (Tamil Nadu). Today, the organisation oversees a number of these shari' ah 'adalats, where female qazis meet with local women (and their family members when appropriate) in designated offices and handle a range of predominantly matrimonial and family issues causing them suffering. They hear cases relating to abuses enacted by husbands including domestic violence, cruelty, unilateral triple-talaq divorce or failure to provide adequate spousal maintenance, as well as grievances relating to in-laws. The qazis advise women on both official/ state-focused means and unofficial/ shari 'ah-based mechanisms to address their problems. In practice, they act both as arbitrators, facilitating either marital separations or reconciliations between estranged partners, and as interlocutors, referring women to a variety of external bodies, including the police, family courts and sympathetic community forums that might offer legal or personal assistance. The largest women's shari 'ah courts, like those in Mumbai and Jaipur, claim to receive around 200 cases each per year; together, the BMMA's shari 'ah 'adalat network has handled thousands of cases since its foundation.

To support the movement, the BMMA has appointed some 20 female graduates as 'qazis' who now work in many Indian states. All have been trained through the Dar-ul-'Uloom-i-Niswan, a training programme set up by the BMMA that takes place over a number of training sessions and gives its graduates a stamp of qualification in qazi at (judgeship). ${ }^{75}$ Predictably, male 'ulama have often challenged these women's ability to make valid decisions according to Islamic law. According to Khatun Shaikh, Mumbai's indomitable head female qazi, local mullahs treated the female qazis with disdain once they began their work, instructing that they should 'sit at home and manage the house', or reminding them that 'your husband is your God'. ${ }^{76}$ Nevertheless, like the women involved in the mosque movements discussed above, these activists have sometimes received cautious acceptance from some male clerics, and in

\footnotetext{
${ }^{74}$ I discuss this movement in more detail in Justin Jones, "Where only women may judge": developing gender-just Islamic laws in India's all-female "shari 'ah courts", Islamic Law and Society $(26,4,2019)$, pp.437-466.

75 BMMA, "Darul Uloom-e-Niswaan Institute of qaziat for women" (2015): this internal document is a syllabus for the training programme.

${ }^{76}$ Interview, Khatun Shaikh, 8 August 2017.
} 
reality these all-female courts sometimes cooperate with some of the more sympathetic male scholars in their own cities to address the problems faced by individual women. ${ }^{77}$

The appointment of female qazis has not been without controversy even among Muslim women's activists, some of whom have distanced themselves from what they perceive as a controversial and provocative departure from the tradition of male-only religious judges. ${ }^{78}$ However, justifying their occupation of a conventionally male position of authority, these female qazis argue that they in fact uphold true Islamic legal principles more authentically than do many of their male counterparts. As Khatun Shaikh argues, male qazis in India often freely approve customs, including male-enacted instant divorce and polygamous marriages, that violate the ethical standards of marital conduct demanded in the Qur'an. ${ }^{79}$ Thus, whenever the BMMA's female qazis find themselves dealing with marital breakdown or divorce, they adhere more closely to the Qur'an's own principles concerning dispute resolution: those of arbitration (tehkim), mediation (sulh) and conciliation (wasatah) ${ }^{80}$ Wherever possible, the qazis seek to maintain communication between parties: sometimes they aim to facilitate reconciliation, or in other cases, they promote negotiated separations, seeking to broker divorces based on the fairest possible settlement. ${ }^{81}$ In this, they claim to differ from the more careless, flippant

${ }^{77}$ Ibid. The Mumbai court especially works with several sympathetic male imams and qazis to whom it can refer its female clients.

78 These include even Na'ish Hasan, the activist mentioned above whose wedding was officiated by a woman. She left the BMMA amidst apprehensions at the appointment of female religious judges.

${ }^{79}$ Interview, Khatun Shaikh. It is worth noting that talaq-i-bid' $a$ h has now been criminalised by the Muslim Women (Protection of Rights on Marriage) Act of 2019, and it seems likely at the time of writing that incidences of this practice are likely to decline.

${ }^{80}$ Ibid. The female qazis, though, argue that where divorce is necessary, it must be enacted via an incremental process which allows space for negotiation or reconciliation (known as talaqi-ehsan) between the couple, as outlined in the Qur'an (e.g. 4:35).

${ }^{81}$ These qazis negotiate a form of divorce that involves the woman's surrender of all or part of her bridal dower (known as khula', but when possible, prefer to seek out a more equable separation does not exact such obligations upon the wife (known as mubarah). Interview, Khatun Shaikh; Jan Maharastra (Mumbai), 22 January 2018. 
approaches to these matters by some male clerics, who give little consideration to women's views and thus can place them in vulnerable situations.

To cultivate this legitimacy as legal authorities, the female qazis, like the founders of women's mosque movements, refer to legitimising figureheads from Islamic history. In particular, they look to the Prophet's wife A'isha, who is lauded as a major legal authority through her issuing of important fatwas (decisions), many of which focused upon women's religious conduct and rights. As is put by Jahan Aara, a passionate, recently certified 'qazi' from Jaipur: 'We have kept our training and knowledge as close as possible to that of the Prophet's wife. At one point, we were on a TV programme with a [male] mufti (jurist), who mocked us by asking whether we had the same level of knowledge as did A'isha. We responded by asking whether today's men have the same kind of wisdom as the Prophet. ${ }^{82}$ By the reasoning of these qazis themselves, they are thus renewing the model of legal interpretation set by the female legal scholars of the Companionate era.

The increasing reach and success of the BMMA's qazis is evidenced in their recent achievement of officiating a Muslim marriage. In January 2019, the BMMA's qazi Hakima Khatun, based in Kolkata, solemnised the nikah ceremony of a Muslim couple from Mumbai who had approached the organisation. This officiation of a nikah at the behest of a Muslim women's organisation was the most high-profile such act since 2008, and gained significant media coverage. ${ }^{83}$ While the qazis of the BMMA's shari'ah 'adalats have received large numbers of approaches in recent years to handle marital breakdowns, they receive few enquiries from couples willing to invite a female qazi to preside over their marriage, whether due to the couple's own reluctance or the fear of disapproval from their families. ${ }^{84}$ This qazi's recent achievement in doing this, the BMMA argues, may now influence 'more Mayas and Shamauns [the names of the couple in question]' to come forward; indeed, some qazis note that

\footnotetext{
${ }^{82}$ Interview, Jahan Aara, 21 August 2017.

${ }^{83}$ Mariya Salim, 'Woman qazi conducts marriage: a victory in women reclaiming spaces taken up by men', https://www.thenewsminute.com/article/woman-qazi-conducts-marriagevictory-women-reclaiming-spaces-taken-men-95855 [accessed 24 June 2019].

${ }^{84}$ Interview, Khatun Shaikh; interview, Nasreen Metai, 3 September 2017.
} 
women whom they have assisted in the past have pledged to come to them to officiate their future (and often second) marriages, or to officiate the marriages of their children. ${ }^{85}$

These female-led shari 'ah 'adalats, like the women's mosque movements, thus comprise bold attempts to renovate accepted religious conventions as a means of overhauling community realities. Appointing female voices able to decide authoritatively on Islamic legal principles, defending women during marital difficulties, negotiating fair divorces and even officiating marriages are all part of a wider ambition to question bastions of male authority such as the mosque brotherhoods and shari 'ah councils that position themselves as the local guardians of family affairs. Moreover, these shari'ah 'adalats illustrate perfectly how India's particular legal framework for handling minority affairs has informed the strategies adopted by Muslim women's activists. With many personal law matters never coming before courts or official bodies, but being adjudicated entirely by religious leaders or community forums, women's groups have had to appropriate equivalent non-state and paralegal strategies for resolving women's problems. While they do routinely refer women to official institutions such as the police or family courts for assistance, they find themselves sometimes needing to confront aspects of Muslim personal law exercised from within local community structures to have real impact. Working as qazis within women-led shari'ah 'adalats has become their mechanism for resolving women's difficulties from inside the framework of local community and everyday religion.

\section{Women claiming the shrine}

Compared with the mosque, madrasa or Islamic court, the confessional structures of Sufism have historically often been more open to female participation. Female saints have been relatively commonplace figures in Islamic history, and have been imbibed with charismatic authority (barakah) equivalent to that of male pirs. Equally, the comparative openness of Sufi orders and shrines to female practitioners have allowed women's meaningful engagement with Sufi piety. ${ }^{86}$ South Asia itself, for instance, has a wealth of historical female saints and shrines

\footnotetext{
${ }^{85}$ Salim, 'Woman qazi conducts marriage'; interview, Khatun Shaikh.

${ }^{86}$ A few elaborations of women's sainthood and participation in Sufi orders include Annemarie Schimmel, 'Women in mystical Islam', in Azizah al-Hibri ed., Women and Islam (Pergamon Press: Oxford, 1982); Valeria Hoffman, 'Muslim sainthood, women and the legend of Sayyida
} 
built in their honour; and women, even when excluded from mosques and community brotherhoods, are frequent visitors to Sufi shrines. ${ }^{87}$ It is thus unsurprising that Sufism has been appropriated in the service of contemporary Muslim women's activism. Globally, a number of Islamic feminist thinkers in recent years have identified Sufism as a source of inspiration for constructing female religious agency. Prominent scholars have recalled stories of Islam's female saints and contemporary mystics ${ }^{88}$ while others like the self-declared Islamic 'feminist' Sa'diyya Shaikh have used the liberating potentialities of Sufism as a basis for recognising spiritual equivalence between genders and developing more gender-equal interpretations of Islamic laws and traditions. ${ }^{89}$ The work of Shaikh and others has hinted at how women's

Nafisa', in Arvind Sharma and Katherine Young eds., Feminism and world religions (Albany, NY: SUNY Press, 1998), pp.107-144; Marcia Hermansen, 'Women in Sufism: Turkey, South Asia, Central Asia, Afghanistan, Iran, Caucasus and the Middle East', in Suad Joseph and Afsaneh Najmabadi eds., Encyclopedia of women in Islamic cultures (Leiden: Brill, 2005), pp.766-770; Daniel Birchok, 'Women, genealogical inheritance and Sufi authority: the female saints of Seunagan, Indonesia', Asian Studies Review (40, 4, 2016), pp.583-599.

${ }^{87}$ E.g. Kelly Pemberton, Women mystics and Sufi shrines in India (Columbia, SC: University of South Carolina, 2010); Shemeen Burney Abbas, The female voice in Sufi ritual: devotional practices of Pakistan and India (Austin: University of Texas, 2002); Pnina Werbner, Pilgrims of love: The anthropology of a global Sufi cult (Bloomington: Indiana University Press, 2004), esp. pp. 113-123, 218-231; Noor Zaidi, ““A blessing on our people”: Bibi Pak Daman, sacred geography and the construction of the nationalised sacred', Muslim World (104, 3, 2014), pp.306-335.

${ }^{88}$ Eg. Fatima Mernissi, 'The story of a contemporary woman mystic' in Ruth Roded ed., Women in Islam and the Middle East: a reader (I.B. Tauris: London, 1999), pp.237-254.

${ }^{89}$ Explaining how Sufism's message of 'spiritual equality translates directly into the realms of social relations and the law,' some of Shaikh's work appropriates Sufi teachings as 'resources for more relevant, enriching and benevolent interpretations' of the Qur'an and shari 'ah respectively. Sa'diyya Shaikh, 'Islamic law, Sufism and gender: rethinking the terms of the debate' in Ziba Mir-Hosseini, Mulki al-Sharmani and Jana Rumminger eds., Men in charge: Rethinking authority in Muslim legal tradition (London: OneWorld, 2014), pp.107-9; c.f. Sa'diyya Shaikh, Sufi narratives of intimacy: Ibn Arabi, gender and sexuality (Chapel Hill: University of North Carolina Press, 2012). 
religious empowerment might be sought in their allegiance to a chosen waali, a Sufi saint, as an alternative to passive deference to a wali, a male family guardian.

Echoing these global trends, women's activists in India have been drawn to Sufism's emancipating potentialities. Activists in this new generation of Muslim women's organisations sometimes suggest that allegiance to a saint can give individual women direct personal guidance, liberating them from the whims of conservative male mullahs who position themselves as middle-men between man and God. ${ }^{90}$ Some women's activists allude to Sufi influence upon their work for women's empowerment in the simple form of broad-brush references to Sufism as proof of Islam's ethics of equality and rightfulness (musawat, sulook). Some recall childhood visits to shrines in Delhi, Ajmer and Gujarat; others talk about drawing their own inspiration from 'mysticism' (a term transplanted directly into Hindi); others still convey their motivations in Sufi-inspired idioms, like receiving guidance from God in dreams. ${ }^{91}$ Some activists also refer to the lives of female saints as inspiration, including figures from South Asia; most strikingly perhaps, some call upon the life-story of Hazrat Baba Jaan, a female Pashtun mystic from Baluchistan, who established fame as a migrant ascetic and miracle-worker in the slums of Pune in the 1900s. ${ }^{92}$ Moreover, a striking number of activists have chosen the names of female saints, like Rabia, Rukaiya and 'Aliya, for their daughters.

Alongside these invocations of Sufi piety, women's activists in some recent cases have ventured to transform aspects of normative Sufi practice that infringe the ethics of equality: for instance, by confronting the male custodial stranglehold over certain Sufi spaces. The key example was a campaign in 2014-16, led by the BMMA, to win women's access to a well-

${ }^{90}$ Interview, Noorjehan Safia Niaz, 28 August 2018. Other Indian feminists have evoked Sufism as a model for gender emancipation. For instance, the liberal-leaning activist Sadia Dehlavi has appropriated South Asia's illustrious Sufi past to call for a renewed non-gendered piety. Citing historic chronicles of woman Sufis and mystics, she explores Sufism as a field of knowledge that has been open to active female participation and can offer women a direct relationship with God. Sadia Dehlvi, 'Mystic women', Times of India, 12 March 2012; c.f. The Sufi courtyard: dargahs of Delhi (Delhi: Harper Collins, 2012).

${ }^{91}$ E.g. Amber, 'Journey of a pedestrian'; Shaista Amber, oral communication.

92 E.g. Na'ish Hasan, oral communication. On Baba Jaan's intriguing biography, see Kevin Shepherd, A Sufi matriarch: Hazrat Babajan (Cambridge: Anthropologia Publications, 1986). 
known Sufi shrine. The dargah of the little-documented saint Pir Haji Ali Shah Bukhari juts out into the ocean via a walkway off the coast of Mumbai, and for most of its existence, it has been open to both male and female worshippers. ${ }^{93}$ In 2012 the dargah's custodian body, the Haji Ali Trust, closed the shrine to women, justifying the decision on the somewhat spurious grounds of protecting women from harassment within the shrine, and because 'their saris might fall off' as they leant over the mazar. ${ }^{94}$ In response, the BMMA's leaders filed a petition with the Mumbai High Court against the Haji Ali Trust, arguing that barring entry to women was an infringement of their constitutional rights to equality and to freedom of religious practice (specifically, Articles 14, 15 and 25). This open challenge to a body that saw itself as deputising for the saint himself was ultimately upheld by the court, leading to the shrine being reopened to female worshippers. The court victory in 2016 was widely celebrated a triumph for Muslim feminists, ${ }^{95}$ and in hindsight, is often interpreted by BMMA members as a precursor to the organisation's significant court victory in the instant triple-talaq judgment in $2017 .{ }^{96}$

This example is somewhat distinct from other cases discussed in this paper in that the BMMA identified the state judiciary as the chosen agent for altering religious conventions. Rather than making interventions into community networks and social institutions as in the other discussed examples, the BMMA turned to the High Court, and it largely argued to exact changes in religious practice on the basis of constitutional principles of gender equality and freedom of religion. Yet, the nature of the court case itself, in which the BMMA's leaders challenged the shrine's hereditary custodians, compelled them to invoke religious claims and cast themselves as cognisant Islamic authorities alongside their position as court petitioners. They assembled

${ }^{93}$ Originally, all entrances and spaces were open to both genders, though at some point, women were conscribed to a separate entrance and space from men.

94 'High Court of Judicature at Bombay, Ordinary Original Civil Jurisdiction; Public Interest Litigation No.106/2014,' Bharatiya Muslim Mahila Andolan Private Papers, Mumbai (henceforth: BMMA Papers).

${ }^{95}$ E.g. Zakia Soman and Noorjehan Niaz, 'What the Haji Ali victory means for India's women', The Wire, 3 October 2016; https://thewire.in/religion/what-the-haji-ali-victory-means-forwomen [accessed 13 March 2018].

96 The BMMA co-filed the Public Interest Litigation that led to the Supreme Court's declaration of talaq-i-bid'ah as unconstitutional and invalid in August 2017. Shayara Bano Vs Union of India (2017). 
documentary evidence that included a compilation of Qur'anic and hadith references upholding women's spiritual equality; statements from well-known contemporary clerics (like Gibril Haddad of Lebanon) supporting female participation in Sufi rites and shrine attendance; and a sociological survey of Mumbai's dargahs claiming that a majority (12 of 19) admitted women. ${ }^{97}$

Moreover, while the campaign was fought through the courts, it was portrayed by its proponents as a quest for spiritual empowerment. BMMA leaders retrospectively present the legal campaign itself in Sufi imagery and idioms, describing their struggle emotively as a spiritual 'journey' (ziyarat) marked by 'triumphs and tribulations' at every 'stage' (maqam), invoking imagery resonant of the Sufi path to fulfilment. ${ }^{98}$ Even more explicit was the ritual of stepping into the dargah soon after the court victory. Having assembled a female crowd to walk along the overpass towards the shrine and gather within the shrine's inner sanctum in an event visually reminiscent of an act of collective pilgrimage and supplication to the saint, the event blurred the imagery of activist rally and religious rite, perhaps affirming the sacredness of India's Muslim women's movement itself.

\section{Conclusions: An activism of religious practice, Islam's 'free church' and} $\underline{\text { Indian secularism }}$

This article has argued that, over the last fifteen years, a new generation of Indian Muslim women's activists have promoted a variety of audacious attempts to experiment with norms of Islamic religious praxis. The appointment of women as imams, marriage officiators and qazis, and campaigns to give women access to sacred spaces like mosques and shrines, have established a particular brand of non-conformist Islamic activism in which Muslim women's activists combine demands for legislative and legal reforms with noisy, high-profile campaigns for the emancipation of everyday confessional structures from male command. While these activists are working through different organisations, their recurrent recourse to matters of

\footnotetext{
${ }^{97}$ BMMA, 'Research based on the Quran and Hadiths'; Gibril Haddad, 'Proofs for visitation of graves by women'; and BMMA, 'Survey of dargahs At Mumbai': Appendices to Public Interest Litigation No.106 of 2014, BMMA Papers.

98 'Indian Muslim women's entry in the Haji Ali Dargah: perspectives and the struggle', manuscript, BMMA Papers; c.f. Interview, Khatun Shaikh; Interview, Jahan Aara.
} 
Islamic conduct and worship collectively distinguishes them from the more singularly socioeconomic and legal focus common to earlier generations of women's and Muslim women's activism in India, as well as women's rights movements across much of the Muslim-majority world.

This distinctive praxis-centred trajectory of Muslim women's activism has developed in India out of a combination of factors. It has drawn strength from the wider dynamics of social change and both global and national trajectories of women's empowerment, as well as India's long history of vibrant civil society activism. In particular, however, I have emphasised that this distinctive incarnation of religious activism is in many ways a product of India's own variant of 'secularism' as a polity for handling religious minority questions. For one, the lack of any 'official' Islamic voice or policy in India has given women's groups space to experiment with religious conduct and create their own forms of Islamic leadership. Furthermore, the principle of guaranteeing the relative autonomy of minority religious institutions and laws, prime among them Muslim personal laws, has meant that women's activists cannot realistically hope to incur meaningful change for Muslim women through pushes for legislative intervention alone. Instead, they have been frequently compelled to address forms of women's inequality that are religious and cultural as well as socio-economic or legal in origin; and thus they have had to concentrate on influencing community 'mindsets' and local structures of patriarchy as a major pathway for enacting meaningful changes. Seeking women's empowerment through remodelled religious praxis is thus best understood as part of the multipolar approach that Muslim women's activists have followed to address the interlocked religious, social and economic needs of the 'triply disadvantaged' Indian Muslim woman.

The various remodellings of norms of Islamic leadership and observance described above are hardly homogeneous in character, nor do they represent identical strategies. Some activists, as I have indicated, have utilised religious observance to foster women's personal agency, which might in turn ultimately empower them in all aspects of their lives. These efforts - facilitating women's access to congregational prayer, for example - seek to expand space for women's religious participation without necessarily disrupting existing structures of Islamic life. In other cases, activists have attempted to inaugurate wholesale overhauls of Islamic norms in order to directly challenge the patriarchal hierarchies embedded in Muslim society. Creating female qazis or mosque jama'ats, for example, are explicit attempts to initiate a wider collective reconsideration of everyday socio-religious realities. 
This paper has also perhaps indicated an evolution in the particular form of contemporary Islamic feminism to which these activists are giving shape. ${ }^{99}$ It has been commonly noted that proponents of so-called Islamic feminism have tended to prioritise the ethical re-reading of Islam's texts and legal principles to build an authentically Islamic discourse of women's equality and justice. By this interpretation, Islamic feminism essentially comprises a predominantly hermeneutic enterprise for recovering progressive Islamic reasoning and legal interpretation. ${ }^{100}$ As such, Islamic feminists have given comparably little attention to matters of religious praxis. According to Margot Badran, Islamic feminism's major acolytes have historically done less to formulate what she calls an 'internal critique' of exclusively confessional matters, such as points of everyday religious observance or structures of clerical leadership. ${ }^{101}$ The examples discussed in this paper, therefore, indicate that these Muslim women's activists in India are developing a more embodied, praxis-focused style of Islamic feminism than the elite, intellectual enterprise of some of their global counterparts. One of the BMMA's leaders cites the need of feminists to focus simultaneously upon 'strategy' (in other

${ }^{99}$ It is worth noting that many of the groups I discuss in this paper do not openly adopt the label of 'Islamic feminists', probably because it might distinguish their cause too far from other women's groups and secular campaigns for rights or equality with which they have shared aims. Nevertheless, the leaders of movements like the AIMWPLB and BMMA align themselves selectively with the global project of Islamic feminism: they are all familiar with the ideas and achievements of major Islamic feminists like Amina Wadud, Fatima Mernissi and Asma Barlas, and echo their ideas in their languages of 'gender justice' and the recovery of a 'spirit of the Qur'an'.

${ }^{100}$ Works that analyse Islamic feminism as a project of evaluating the meaning of Islamic texts and ethical principles include Aslan et al eds., Muslima theology; Ayesha Hidayatullah, Feminist edges of the Qur'an (New York: Oxford University Press, 2014); Karen Bauer, Gender hierarchy in the Qur'an: medieval interpretations, modern responses (Cambridge: Cambridge University Press, 2015).

101 This is in contrast to Christian and Jewish feminists, who since the 1960s have developed identifiable 'religious feminisms' that are distinct, 'specialised [and] compartmentalised' on issues particular to their own traditions, including 'refigur[ing] the practice of religious ritual [and] opening up new roles for women as ministers and rabbis and for "unordained" women as leaders of congregational prayer'. Badran, Feminism and Islam, pp.220-21. 
words, speculating upon ways to pursue the macro-project of women's empowerment), and upon 'practice', by which these efforts can be translated into real, grassroots impacts for ordinary women. ${ }^{102}$ While Islamic feminism has sometimes been criticised for being a remote and elitist hermeneutic exercise, ${ }^{103}$ these Indian feminists are reworking confessional practices to develop an alternative manifestation of Islamic feminism that interacts with and informs ground-level realities of religious observance and organisation.

Crucially, this paper has also suggested that these women's activists' remodellings of religion are dependent upon India's particular religio-political framework, which has set the context in which women's associations in India have been able to engage in open and bold experiments with everyday religious practices. Indeed, India's discursive secularism and comparatively open civil society institutions have created conditions for an Islam that can be, as one leading activist put it, a 'free church', whose character and destiny is determined by its members. Islam, she argues, is a religion that allows every person his or her own relationship with God and an ability to judge religious teachings for themselves; and likewise, constitutional 'secularism' should protect the rights of every person to develop and express his or own version of their religion. ${ }^{104}$ Her claim alludes to a valued political context in which the state itself has historically refrained from extensive systematic interventions into religious leadership or customs, meaning that no single claim to speak for Islam has a priori precedence over another. This has given Muslim women's activists a cherished ability (and, indeed, a constitutional right) to experiment with confessional ideas and practices in ways that would be unfeasible in many other Muslim societies. ${ }^{105}$

${ }^{102}$ Niaz, 'Women's shariah court', pp.10-11, c.f. Jones, "“Where only women may judge", pp.443-44.

103 As alluded to in e.g. Badran, Feminism and Islam; Hidayatullah, Feminist edges of the Qur'an.

${ }^{104}$ Interview, Zakia Soman.

105 Groups like the BMMA frequently compare themselves to equivalents elsewhere such as Malaysia's Sisters in Islam, founded in 1989. BMMA leaders argue that their movement shares with the latter a more proactive approach to rethinking Islamic texts and observances, and a deliberate blending of Islamic and secular principles of equality and justice. This is something possible for both organisations since, the BMMA argues, they operate within wider civil society space than do women's organisations in many Middle East nations, whose engagements 
However, this interpretation suggests that this experimental brand of Muslim women's social activism depends upon a framework in which the Indian state continues its long-held propensity to, as Partha Chatterjee puts it, 'stay away from pushing an interventionist agenda... with respect to the institutions and practices of minority communities. ${ }^{, 106}$ As this article has argued, it is the state's long-term (if variable) 'principled distance' from the laws and institutions of the Muslim minority that has provided Muslim women's and other groups with the discursive and operational space to make their own alterations to religious conventions. However, these conditions are currently in flux, amidst the turn to an assertive anti-secularism in contemporary Indian politics. Indeed, alongside these re-modellings of Islam by Muslim women's groups discussed in this paper, there have also been government attempts to push the boundaries of the state's traditional position of non-interventionism in minority religious matters; for instance, in its enthusiasm to legislate upon the Muslim personal law issue of triple-talaq. ${ }^{107}$ Recent years have also seen fresh attempts by resurgent civil society Hindu organisations to urge the Indian courts to curb Islamic religious practices, including banning the niqab and obliging mosques to admit women. ${ }^{108}$ These examples together illustrate how the older convention of conscribing matters of religious practice as solely community affairs has been subject to increasing challenge.

While some of these concurrent efforts from outside the Muslim community to reform Islamic practices may superficially resemble the efforts of some Muslim women's associations in their

with religious precepts have therefore been more restrained. Ibid. See also Azza Basaruddin, Humanising the sacred: Sisters in Islam and the struggle for gender justice in Malaysia (Seattle: University of Washington Press, 2015), especially pp.220-221; Yasmin Moll, "People like us" in pursuit of God and rights: Islamic feminist discourse and Sisters in Islam in Malaysia', Journal of International Women's Studies (11, 1, 2009), pp.261-289.

${ }^{106}$ Partha Chatterjee, The politics of the governed, p.127.

107 The BJP government passed the Muslim Women (Protection of Rights on Marriage) Act, which invalidated and criminalised talaq-i-bid' $a$ h, in July 2019, following two years of attempts to see the bill pass successfully through both houses of the legislature.

108 These were attempted, respectively, by the Shiv Sena nationally, and Akhila Bharatha Hindu Mahasabha in Kerala in 2019. E.g. India Today 30 April 2019; Times of India, 10 October 2018. 
intentions, they also cause difficulty for these same groups. On past occasions in postcolonial India at which Indian Muslims have felt their religious practices to be under threat from the state or non-state actors, we have often witnessed a subsequent reassertion of conservative community norms. In turn, this has often impacted especially upon the rights of Muslim women, whose voices are submerged under the invocation of community interests. ${ }^{109}$ Those sympathetic to the brands of Muslim women's religious activism discussed above therefore might hope that the current climate of social and political besiegement felt by many Indian Muslims does not ultimately curtail the space open to these women to discuss, contest and act upon the everyday practices of their religion.

109 The Shah Bano case is often given as the archetypal example of this trend. For just a few examples of this argument, see Flavia Agnes, Law and gender inequality: the politics of women's rights in India (Delhi: Oxford University Press, 2001); Zoya Hasan, 'Gender politics, legal reform and the Muslim community in India', in Patricia Jeffery and Amrita Basu eds., Appropriating gender: women's activism and politicized religion in South Asia (New York: Routledge, 1998), pp.71-88; Nivedita Menon, Recovering subversion: feminist politics beyond the law (Urbana-Champaign: University of Illinois, 2004); Rajeshwari Sunder Rajan, The scandal of the state: women, law and citizenship in postcolonial India (Durham NC: Duke University Press, 2003); Sylvia Vatuk, 'A rallying cyy for Muslim Personal Law: the Shah Bano case and its aftermath', in Barbara Metcalf ed., Islam in South Asia in Practice (Princeton: Princeton University Press, 2009), pp.352-367. 